\title{
Inculcation Religiosity in Preschoolers Local content curriculum
}

\author{
Watik Rahayu ${ }^{1}$ \\ TK Aisyiyah Cabang Kartasura \\ Muhammad Munadi ${ }^{2}$ \\ IAIN Surakarta, Indonesia
}

DOI: https://doi.org/10.21009/JPUD.132.01

Accepted: August 15 ${ }^{\text {th }} 2019$. Approved: September $4^{\text {th }} 2019$. Published: $30^{\text {th }}$ November 2019

ABSTRACT: Millennial era life is a big challenge, humans need a strong footing to face all the problems. Religion is God's guidance that becomes the handle of life and it is important to instill religious beliefs early on. The purpose of this study was to find the cultivation of religiosity in preschool children in Kindergarten Aisyiyah Branch and Kindergarten Santa Maria in Kartasura Regency. This study uses qualitative methods with data collection tools, namely interviews, direct observation, and document analysis. Data validated using triangulation of methods and sources. The results showed that the religiosity of planting in the TK Aisyiyah Kartasura branch had more burdens than in the Santa Maria Kindergarten. While its nature is more balanced between vertical ritual content and horizontal content in TK Aisyiyah Kartasura branches compared to TK Santa Maria. The cultivation of moral education is carried out through a step-by-step process starting with teaching to say and answer greetings (Islam), saying good morning and evening to non-Muslims and inviting children to always pray in every activity. Vertical ritual planting in TK Aisyiyah Kartasura branch has more burden through the practice of prayer, memorizing prayers and memorizing short letters from the Qur'an all in Arabic compared to TK Santa Maria only emphasizes the memorization of prayer in Indonesian.

Keywords: Inculcation religiosity, Pre-schoolers, Local content curriculum

\footnotetext{
${ }^{1}$ Corresponding Author:

Watik Rahayu

Email: watikrahayu2010@gmail.com

${ }^{2}$ Email: munadimahdiputra@gmail.com
} 


\section{INTRODUCTION}

Religious faith, beliefs, and activities are important aspects of the lives. Although researchers have found a general age trend for religiousness to decline from childhood through adolescence (Bridges $\&$ Moore, 2002). The importance of religious education makes it obligatory to be taught from an early age. research Heiphetz, Lane, Waytz, \& Young, (2016) shows that children's religious cognition often matches the implicit responses of adults, revealing anthropomorphic ideas about God's mind The year 2009 was the year of the launch of Early Childhood Religious Education, which was established by the Minister of Religion. Religious education carried out early makes students not only get religious understanding correctly but also avoid the dangers of negative influences such as drugs. The minister of religion does not believe that if a person obtains a true understanding of religion, it will give birth to fanaticism, early religious education also creates children to understand all forms of difference from every existing religion. In addition, it makes children understand that every religion does not teach something negative. In Indonesia, everything is more possible for parents and educational institutions to offer religious education from an early age for children with all the atmosphere and religious aura that is more pronounced.

The age of children is a time when things are easily formed and will find how their future will be. Children 5-7 years prefer teleological explanations, but this preference diminishes with age. Children find teleological explanations more useful than adults. Therefore, understanding goals in life events is rooted in childhood, which has the potential to show more general sensitivity to goals in the social and natural world (Banerjee \& Bloom, 2015). That is what underlies the importance of research conducted so that a person will not make fatal mistakes in shaping the child's religiosity in his childhood. Someone who in his childhood gets guidance, childcare, education, experience, and training in matters that are religious, polite and light-handed (such as helping) to others, empathy for distress and all social problems in the surrounding environment, then after adulthood, he will feel the importance of religious values in his life and personality towards religious maturity.

Childhood studies place emphasis on children's agency, their ability to understand their own world and act upon it. Children actively participate in meaningful social interactions in both formal and informal settings. It is vital to understand how children interact in an increasingly diverse world where they meet cultural and religious difference. The results of (Rissanen, Kuusisto, Hanhimäki, $\&$ Tirri, 2018) research with children show the role of agency in developing religious knowledge and forming inter-ethnic friendships, and the crucial role schools play in empowering pupils to interact with an increasingly diverse society. Religion direct the behavior of children and adolescents to good behavior at an early age, it greatly influences the development of children in the later stages.

The notion of religion, religious institutions and their function are social constructs. Meaning religion is not an 'object' that exists external to and unaffected by the interpretations and actions of social actors, rather individuals play an active role in the construction of the social reality of religion and its place in society. It must be acknowledged that religion, like culture, 'has a reality that persists and antedates the participation of particular people and shapes their perspectives', but this should be understood as a 'point of reference' only, that is constantly being reinvented and reinterpreted by social actors. Succinctly writes, religion can be considered 'an historical and human variable, a social and cultural system and discourse' (Davies, 2019).

Pre-schoolers live in the world of play. Cultivating religion in early childhood through various methods. (Kienstra, van Dijk-Groeneboer, \& Boelens, 2018) found a method that focuses on how early childhood can stimulate learning through these religious stories, to show relationships with 
their own values and truths. High thinking skills in children, namely the effectiveness of religious thought through learning that is of interest and the role of the teacher playing is important to improve religious thinking in early childhood. The curriculum for pre-schoolers have to more flexible, according to the abilities and interests of children. But it is still found that in many Early Childhood institution, curricula that carry out inflexible religious education activities and the material is very heavy. Many religious education materials are not suitable for the age of child development so that children are actually burdened by religious education. This makes children less comfortable and less enjoy religious education in the psychological development of children.

Suyadi, Destiyanti, \& Sulaikha, (2019) research shows that the development of religious-moral values in early childhood is not achieved because of the behavior of children who are not noble, poor quality of morals, and lack of concern for the school environment. This research also shows that there are internal and external factors that become the achievement of religious-moral values in elementary age children because the curriculum with religious content is too heavy and does not focus on developing values in daily life and moral development, but is more focused on memorizing. This shows the importance of planting religious education in early childhood. Therefore, the purpose of this study is to find out inculcation religiosity in the branch of Aisyiyah kindergarten and the Santa Maria kindergarten in Kartasura regency.

\section{THEORITICAL STUDY}

\subsection{Early Childhood Religiosity}

Children's religiosity elucidates recurring themes which contribute towards describing spirituality. A key theme arising in the broader literature on spirituality is that it is widely held to be an innate aspect of being human. Children are thus often believed to have a natural capacity to be spiritual; something which education has the potential to nurture. Four types of consciousness emerged from conversations with the children. These were relationships with self, other, the world and God/the transcendent. Other conceptualizations of the relational have emerged. For example, Fisher, (2013) has developed a quantitative tool, the Spiritual Health and Life-Orientation Measure (SHALOM), to assess four domains of relationship which he classifies as relationship with self, others, environment and God/the Divine (Adams, Bull, \& Maynes, 2016). With regards to relationships with self, identity is a core theme. Within identity, the search for meaning and purpose in life emerges as another central tenet of spirituality. For some, the search relates to the transcendent, which many call God. This search engages with the ultimate questions posed by humankind: Why are we here? What happens after death? Is there a God? children are natural philosophers, instinctively asking these kinds of questions.

To study children's religiosity at the beginning of the twenty-first century provides a prime opportunity for exploring the personal, social and global interconnections in the understanding and practice of spirituality. Countless definitions of spirituality have been suggested, yet it has also been said that spirituality escapes definition altogether. Open-ended description which can be applied to childhood where the fabric of human life first emerges, is nurtured into further growth and shaped towards its adult expression. King, (2013) show on the spiritual potential of childhood, its awakening and development relate closely to the development of the spiritual potential of children.

To attract children's spiritual potential into conscious spiritual awareness requires sensitive teaching from the earliest childhood onwards, through formal and informal education by parents, teachers and friends. It is necessary to develop spiritual literacy in a more intensive manner than is happening 
now. Spiritual intelligence is associated with more comprehensive spiritual literacy in its application. Spiritual literacy does not only develop by itself; it needs to be nurtured and nurtured, it needs to be sown to grow and develop. For this, spiritual education is important at all levels, not only for children and adolescents, but everywhere, at home and at school. Spiritual literacy needs to be an integral part of lifelong learning to begin the global spiritual awakening that is urgently needed in the world today, so that the human species can evolve into greater fulfilment of life (King, 2013). Educational efforts are reconnecting and integrating spiritual and religious into early childhood education. Give children renewed and re-created religious traditions that are appropriate for millennial times and for each generations (Scott, 2014).

Spiritual development refers to a person's involvement with what he considers sacred, divine, or outside the material world. Religion, on the other hand, creates doctrines, beliefs and rituals that bind believers with this process and with each other. Curriculum development of the value of spirituality in early childhood through religion-based learning will develop aspects of children's moral and social development (Benson, Scales, Syvertsen, \& Roehlkepartain, 2012). Oftentimes, the micro and macro systems in the child's environment are in harmony, such as when a child is treated with warmth and acceptance by caregivers in a culture where most people have a belief in God the Most Good. However, micro and macro systems can also experience disharmony. For example, a child taught at home that God is real but immaterial can attend school in a secularrationalist education system that features secular / materialist metaphysics, and where God is rarely mentioned if ever mentioned (Granqvist \& Nkara, 2017).

The importance of religious cultivation at an early age is to reduce the deterioration of mental health in adulthood. Significant associations between childhood difficulties and adult mental health have been documented in epidemiological and social science research. The research recommendations Henderson, (2016) suggest some support for religious involvement in moderating or protecting the harmful effects of childhood difficulties on self-esteem. Religion if not properly cultivated from an early age can also strengthen adverse effects on adult mental health.

\subsection{Early Childhood Religiosity Education Materials}

A critical literature review of early childhood spirituality to move further towards an understanding of what is characteristic of children's spirituality. Ontological issues surrounding the concept of spirituality in the wider literary context are explored, relevant themes are given that many practitioners seek definitions to facilitate the implementation of information from their respective curricula (Adams et al., 2016).

Early education materials for children from 0 to 6 consist of:

(1) Sensory Material: Here the child learns a lot from the senses, then the material delivered must support the cognitive aspects of sensory cognition, such as by introducing the child to the names of objects he sees, hears, and touches with his senses. It can also be done by showing the material with pictures or toys.

(2) Intuitive Material: Here the child must develop his feelings or intuition, the right way is to provide material in the form of songs, for example Pelangi-pelangi alangkah indahmu (Rainbows, you are so beautiful). With the introduction of material in the form of songs, it is expected that children can develop intuitively well.

(3) Fantasy Material: For cognition, fantasy material provided is in the form of material that makes the child's fantasy develop like stories or fables which in itself makes the child develop his fantasy. 


\section{METHOD}

This research uses qualitative research. This means that this research does not use statistical formulas in the analysis but more words from the object under research because the results collected is data on the implementation description in a process, namely the process of Inculcation religiosity in the Kindergarten, Aisyiyah Branch Kindergaten and Santa Maria Kindergarten, Kartasura.

The research conducted in the Branch Aisyiyah Kindergarten and Santa Maria Kindergarten with 17 children and 4 teachers for Aisyiyah Kindergarten, and Santa Maria with 30 children and 3 teachers as well as 4 extras who carried out different religiosity learning activities. It is different from the background of religion in the two institutions. The Aisyiyah Kindergarten is under the Islāmic religious organization of Muhammadiyah while the Santa Maria Kindergarten is under the auspices of Canisius the Catholic religion representations.

Data collection techniques use interviews, direct observations and document analyses with a focus on the inculcation of religiosity in existing classes, places of worship used in the process of religious learning as well as areas of Faith and Piety (iman dan taqwa).

Data validity used in this research is methods and sources triangulations. The data obtained considered valid, with using a variety of sources (multiple sources) with one research focus. The data obtained from the documentation through observation and interviews with one research focus or vice versa. Thus, the data are relatively similar between those obtained with source triangulation and method triangulation.

Data analysis in this research using an interactive model. This means the process of organizing and into basic patterns, categories and description units so that themes found. Achievement of this research theme through data reduction is summarized, sorted out the main things, focused on important things, looking for themes or patterns.

\section{RESULT AND DISCUSSION}

\subsection{Result}

4.1.2. Inculcation Religiosity in Preschoolers in the Aisyiyah Kindergarten Branch Kartasura 2018/2019 Academic Year

Aisyiyah Kindergarten Branch Kartasura is an educational institution based on Islam with a Muhammadiyah religious organization background in the field of women namely 'Aisyiyah. Based on that, this institution uses 2 curricula related to the Inculcation of Religion and Noble Morals. The curriculum refers to the curriculum set by the Ministry of National Education and the Local Content Curriculum is in accordance with the Characteristics of Aisyiyah/Muhammadiyah's education so that the religious content is more dominant. And the number of hours of religious content is also a lot and varied. That was stated by the Aisyiyah Management Branch Kartasura:

"The curriculum at this institution uses 2 references. Ministry of National Education's reference so that students master competencies according to the graduate competency standards set by the ministry. In addition, students are also able to develop competencies in accordance with the spirit of this institution, namely Muhammadiyah/Aisyiyah.” 
The statement shows that Aisyiyah Kindergarten students are directed to become Indonesian Muslims who are humble according to the conditions and situation of Indonesia. This is consistent with the vision which states that:

"The realization of a generation of muslims who have faith and noble character as well as intelligent, independent, and creative".

The vision states that the main target of this educational institution is to make students who have faith and noble character in addition to making students smart, independent, and creative. The vision is described in the mission as follows: (1) Laying the foundation of aqeedah in accordance with the Qur'an and Sunnah; (2) Forming morality and personalities of muslim people who are pious, independent, creative and intelligent in accordance with Islamic values as a provision to live together in the midst of family and society; (3) Help lay the foundation towards the development of attitudes, behaviors, knowledge, skills, and creativity needed by students in adjusting to their environment and for further growth and development.

The vision and mission show that Aisyiyah Kindergarten strives for students who have faith and are well-mannered. To achieve this vision and mission, the institution follows it up in the curriculum of Religion and Noble Ethics which refers to the Ministry of National Education decree on the National Education Minister Regulation No. 58 on PAUD Standards. This was stated by the head of 'Aisyiyah Kindergarten:

"The curriculum used by our institution refers to the Ministry of Education Regulation on Early Childhood Education Standards and the curriculum is in accordance with the provisions of Aisyiyah which are local content."

In accordance with the standard provisions stipulated by the Ministry of Education, the scope of development of Kindergarten students is related to Religious and Moral values in the form of responding to matters related to religious and moral values which include: (1) Beginning to imitate the movement of prayer in accordance with the religion; (2) Beginning to imitate short prayers according to his religion; (3) Beginning to understand when to say hello, thank you, sorry, and so on.

These provisions are in accordance with the level of development achievement of children aged 23 years. While at the age of $3-<4$ years, the scope of the development of values with religious and moral values is in the form of responding to matters related to religious and moral values which include: (1) Beginning to understand the notion of opposing behavior even though it has not always been done such as understanding good-bad, right-wrong, polite-disrespectful behavior; (2) Beginning to understand the meaning of pity, and love for God's creation.

The curriculum is strengthened with local content which includes aqidah-akhlak (morality and belief in One God), A1 Qur'an \& Hadits, Worship, Shirah, and Aisyiyah-an and Kemuhammadiyahan. The explanation was conveyed by the head of Kindergarten 'Aisyiyah as follows:

"On the content of Moral Aqeedah, students are directed to be able to master basic competencies: knowing the pillars of faith as the main aqidah of a Muslim, knowing morals towards oneself, knowing morals towards others, and getting to know the environment." 
The curriculum of The Islamic Religious Education local content of Branch Aisyiyah Kindergarten written in the following table:

Table 1. Moral Aqeedah Content

\begin{tabular}{|c|c|c|}
\hline Basic Competency & Learning Outcome & Indicator \\
\hline \multirow[t]{5}{*}{$\begin{array}{l}\text { Children know the pillars of } \\
\text { faith as the basic Aqeedah } \\
\text { of a Muslim }\end{array}$} & $\begin{array}{l}\text { Are able to know } \\
\text { Allah, Allah's } \\
\text { asthma, and His } \\
\text { creation }\end{array}$ & $\begin{array}{l}\text { Mention the objects of Allah's creation } \\
\text { Distinguishing the creations of Allah } \\
\text { and man-made Are able to call the } \\
\text { tayibah (takindergartenir, tahmid, } \\
\text { tasbih, and tahlil). }\end{array}$ \\
\hline & $\begin{array}{l}\text { Are able to Know the } \\
\text { Angel of God }\end{array}$ & $\begin{array}{l}\text { Mention the names of } 10 \text { angels and } \\
\text { their duties. }\end{array}$ \\
\hline & $\begin{array}{l}\text { Are able to get to } \\
\text { know the Prophet and } \\
\text { Apostle }\end{array}$ & $\begin{array}{l}\text { Mention } 25 \text { names of prophets and } \\
\text { apostles } \\
\text { Exemplify } 4 \text { characteristics of the } \\
\text { prophet. }\end{array}$ \\
\hline & $\begin{array}{l}\text { Are able to get to } \\
\text { know God's Books }\end{array}$ & $\begin{array}{l}\text { Know the books of God revealed to the } \\
\text { Prophets. Know the book of A1 Qur'an } \\
\text { as a guide to Muslim life. } \\
\text { Know the etiquette of the Qur'an }\end{array}$ \\
\hline & $\begin{array}{l}\text { Get to know the End } \\
\text { Times }\end{array}$ & $\begin{array}{l}\text { Know at the end of the day. Know the } \\
\text { existence of heaven and hell. }\end{array}$ \\
\hline
\end{tabular}

The first learning outcomes in the form of material about knowing God, the names of Allah, and His creation are implemented through the singing method. The verses of the song are as follows:

Asy-hadu ala ilaha illa-Allah

Wa asy-hadu anna Muhammad ar-Rasulullah

My testimony that of There is no God but Allah

And my testimony that of Prophet Muhammad was the messenger of Allah.

After the Question and Answer, continue singing with the following teacher and students:

I love Allah... 2x you too ... 2x

I love the Prophet... 2x you too, .2x

The children together with the teacher are eager to sing the verses of the song interspersed with questions and answers, so the classroom conditions are very dynamic. Dynamics can be seen from the process of singing and question and answer conducted by the teacher with answers from students who are very enthusiastic with a strong and loud tone. The second learning outcome in the form of material about knowing the angel of God is carried out through the method of singing. The verses of the song are as follows:

There are 10 angels of God

Who carries out God's commands?

There is an angel of death

There is also a generous person

Jibril, Mikaeel, Izroil, Israfil,

Munkar, Nakir, Rokib, Atid,

Malik and Ridwan

Children with singing actually practice having fun when they receive religious knowledge, so that it does not seem tense, even facilitating children's memorization. The third learning outcome in the form of material about knowing the Prophet of God is applied through the method of singing. The 
third learning outcome in the form of material about knowing the Book of God is applied through the method of poetry.

The material shows that the Aqeedah curriculum directs students to understand their own religion and the religion of others. This can be seen in the introduction to be able to understand and know God's books from the Book of Psalms, the Torah, the Gospel and the Qur'an. In addition, 25 prophets/Apostles were introduced who brought different treatises/revelations to different religions. The explanation shows that in the learning of religiosity in the field of aqeedah, children are introduced to the concept of Aqeedah through song and poetry. Aqeedah strength is strong and can respect differences that can lead children to do good. So the moral code is very simple. The picture is as follows:

Table 2. Moral Aqeedah Content

\begin{tabular}{lll}
\hline Basic Competency & Learning Outcome & \multicolumn{1}{c}{ Indicator } \\
\hline $\begin{array}{l}\text { Children know morals } \\
\text { towards themselves }\end{array}$ & $\begin{array}{l}\text { Accustomed to } \\
\text { Discipline behavior }\end{array}$ & $\begin{array}{l}\text { Implement the rules/procedures } \\
\text { Carry out daily activities with Islamic } \\
\text { manners } \\
\text { Pray according to the situation and } \\
\text { conditions }\end{array}$ \\
\hline & $\begin{array}{l}\text { Are able to show } \\
\text { confidence }\end{array}$ & $\begin{array}{l}\text { Doing the work, yourself } \\
\text { Convey } \\
\text { their wish }\end{array}$ \\
& $\begin{array}{l}\text { Show } \\
\text { proud } \\
\text { to masterpiece }\end{array}$ \\
& $\begin{array}{l}\text { Carry out the task thoroughly } \\
\text { Know one's own/others' belongings } \\
\text { Put something back in its place. } \\
\text { Maintain cleanliness and neatness }\end{array}$ \\
\hline
\end{tabular}

The indicators of implementing the rules 'Aisyiyah Kindergarten Branch Kartasura makes rules/regulations for students and who deliver students. This code is posted on the bulletin board in front of the entrance. In addition, parents of students are given orientation at the beginning of entering the new school year and given a copy observed at home. The pattern is so that there is a work together between the school and the family and mutual support.

The second indicator is that the child carries out daily activities in an Islāmic way, achieved by giving children the obligation to wear Muslim and Muslim clothing every day. This is to train children to want to close their genitals early on. The other children when they want to enter the gate are welcomed by the teacher by greeting and shaking hands. That way children know and practice the habit that when they meet, they have to say hello, greet and smile to others.

Achievement indicators are that children are able to say prayers according to situations and conditions by means of children being trained to read prayers when entering the school gate, want to go to school, start learning and end learning. These three indicators try to discipline the child to adjust to school regulations.

Learning outcomes in the form of children can show self-confidence achieved by making a code of conduct for introductory children are only allowed to arrive at the front gate of the school and children not be watched while at school even outside the school fence. Children accompanied by 
an introduction only during the first week of the new school year. That way children exercise independently and do not always depend on others. They practice doing what their teacher assigned themselves. Moral Materials about morality towards others described as follows:

Table 3. Moral Aqeedah Content

\begin{tabular}{lll}
\hline Basic Competency & Learning Outcome & Indicator \\
\hline $\begin{array}{l}\text { Children know morals } \\
\text { towards others }\end{array}$ & $\begin{array}{l}\text { Accustomed to the } \\
\text { mandate }\end{array}$ & $\begin{array}{l}\text { Ask for permission if using someone else's } \\
\text { Take care of another people's property } \\
\text { Return borrowed items }\end{array}$ \\
\hline
\end{tabular}

The above indicators are achieved with a variety of learning. Children are trained to ask permission from the teacher when they want to use the game equipment owned by the school. When the game equipment is scattered less organized, children are invited to rearrange together to be organized and placed on the toy rack available.

In addition to children knowing morals towards fellow humans, Kindergarten children 'Aisyiyah is taught about knowing morals towards the environment, animals, and plants and protecting the environment. The picture is in the following table:

Table 4. Moral Aqeedah Content

\begin{tabular}{lll}
\hline Basic Competency & Learning Outcome & \multicolumn{1}{c}{ Indicator } \\
\hline Children know morals towards & Love animals and & Love animals \\
the environment & plants & Care for plants \\
\hline
\end{tabular}

To get to know the character of the environment both animals and plants, children are given a song about the types of animals. The verse is as follows:

Sheep sheep

Fish fish

Chicken chicken

Cow cow

When the teacher sings this stanza with the child demonstrating the types of animals. Flap both hands for the sheep and say chicken. When declaring fish-like swimming and when calling Cow fingers point forward. Singing and modeling make children live concretely the types of animals. In addition to singing, children are given fable stories about animals that worship. Like Mio (cat), who is friendly with Sali so that all activities of Sali are always followed, including when Sali is praying, even if she is pulling Sali's blanket to get up early and do dawn prayers. Like the following song lyrics,

"Every day I wake up in the morning, I fold the blankets neatly, continue to shower and brush my teeth at dawn prayers do not forget anymore".

In addition to Aqeedah and Morals, children are given the contents of the Qur'an and Hadith. Description of the material as follows:

Table 5. Al-Qur'an \& Hadith Content

\begin{tabular}{lll}
\hline Basic Competency & Learning Outcome & Indicator \\
\hline
\end{tabular}




\begin{tabular}{lll}
\hline Children are able to & Are able to memorize & Memorize letters in the Qur'an \\
memorize short letters in & short letters in the Qur'an & 1. Al Fatihah \\
the Qur'an & well, correctly and & 2. An Naas \\
& precisely & 3. Al Falaq \\
& & 4. Al Ashr \\
& 5. Al Kautsar \\
& 6. Al Lahab \\
\hline
\end{tabular}

Memorizing short letters is done every day, especially the Al-Fatihah and Al Ashr. Al Fatihah is read when the initial prayer enters class, then another short letter after reading the prayer. In accordance with the Aisyiyah curriculum in semester 1, I memorize the letter An Naas and Al-Falaq. And Al Ashr's letter is always read when going home. When children have not memorized the memorization by imitating their teacher first by beheading the correct verse and then imitating the children. In addition to children being monitored memorizing short letters in the Qur'an is also given memorization of short prayers in daily life. The material is in the following table:

Table 6. Al-Qur'an \& Hadith Content

\begin{tabular}{lll}
\hline Basic Competency & Learning Outcome & Indicator \\
\hline Children are able to & Are able to & Memorize and practice daily prayers \\
memorize daily & memorize daily & 1. Prayers before studying \\
prayers & prayers & 2. Prayers for traveling \\
& 3. Prayers for using the vehicle \\
& 4. Prayers before and after meals \\
& 5. Assembly closing prayers \\
& 6. Prayers for both parents \\
& 7. Pray for the good of the world and the here \\
& after \\
& 8. Prayers after ablution \\
& 9. Prayers after the call to prayer \\
& 10. Prayers before and after meals \\
& 11. Prayers for visiting sick people \\
& 12. Prayers when you sneeze \\
13. Iftar prayers \\
14. Prayers for mirroring \\
15. Prayers in and out of the toilet \\
16. Prayers in and out of the mosque
\end{tabular}

The way to memorize the prayers above is the prayer before learning is always read at the beginning of the lesson and traveling prayer is always read at the end of the lesson/prayer when going home. Prayers before and after meals are always read every day at rest (meals). Other prayers memorize them according to the schedule, which is Tuesday, sometimes they are also memorized when certain conditions such as a child sneezing, and at that time they also memorize a prayer when sneezing. The memorization of the prayers above is the first that the teacher has just mimicked the children than two/three children are told to mimic those whose voice is loud/eager to imitate the child will get a star image. Such habituation can make children conditioned to always read prayers whenever, whenever and wherever. 
In addition to the child being able to memorize as described above, the child is also trained to memorize and practice short traditions with polite manners towards themselves and others. This is given to children so that from the beginning they are able to have good manners to anyone, anything and at any time. The following table illustrates the material about short traditions about modesty.

Table 7. Al-Qur'an \& Hadith Content

\begin{tabular}{lll}
\hline Basic Competency & \multicolumn{1}{c}{ Learning Outcome } & \multicolumn{1}{c}{ Indicator } \\
\hline Children are able to & Are able to memorize & Memorize the hadiths and practice \\
memorize and practice short & the hadiths and practice & them: \\
traditions in daily life & them in everyday life & $\begin{array}{l}\text { a. Hadith concerning the ban on } \\
\text { anger }\end{array}$ \\
& $\begin{array}{l}\text { b. The hadith concerning smiles } \\
\text { c. Hadith concerning spreading } \\
\end{array}$ \\
& greetings \\
\hline
\end{tabular}

Hadith taught to children is a short tradition that is easily memorized by children and can be practiced immediately. When the child is angry with his friend, the teacher immediately reads the Hadith about the prohibition of anger. Likewise, when a child frowns, the child is recited from the Hadith command to smile. With this kind of model, children are warned gently without offending children.

In addition to introducing the material Aqeedah Morals and the Qur'an, the Hadith children are given a vertical worship load that is related to the pillars of Islam, ablution, and prayer with practice. The material is as follows:

Table 8. Prayer Content

\begin{tabular}{|c|c|c|}
\hline $\begin{array}{l}\text { Basic Competency } \\
\text { Children are able to } \\
\text { recognize, memorize, } \\
\text { and practice the } 5 \\
\text { aspects of the pillars of } \\
\text { Islam in everyday life }\end{array}$ & $\begin{array}{l}\text { Learning Outcome } \\
\text { Are able to memorize } \\
\text { the pillars of Islam }\end{array}$ & $\begin{array}{l}\text { Indicator } \\
\text { 1. Say the two sentences of the Shahada } \\
\text { 2. Mention the pillars of Islam correctly. }\end{array}$ \\
\hline & $\begin{array}{l}\text { Are able to perform } \\
\text { procedures for ablution } \\
\text { properly and correctly }\end{array}$ & $\begin{array}{l}\text { 1. Perform procedures for ablution } \\
\text { 2. Get to know things that are } \\
\text { Cancel ablution } \\
\text { 3. Know tayammum } \\
\text { 4. Get to know various kinds of holy water } \\
\text { and purify }\end{array}$ \\
\hline & $\begin{array}{l}\text { Are able to do the } \\
\text { movements and } \\
\text { recitation of prayer } \\
\text { correctly }\end{array}$ & $\begin{array}{l}\text { 1. Mention and } \\
\text { Demonstrate prayers } \\
\text { 2. Pronounce recitation of prayer correctly } \\
\text { 3. Know the times of the obligatory prayers } \\
\text { 4. Know the number of rak'ahs in prayer } \\
\text { 5. Recognize the recitation of dhikr after } \\
\text { prayer. }\end{array}$ \\
\hline
\end{tabular}

The material above shows that children are introduced to the full pillars of Islam from the Creed, Prayer, Fasting, Zakat, and Hajj. In this semester the strengthening lies in the first pillar of Islam and the second pillar, Creed, and Prayer. When introducing the recitation of the shahada, the teacher and the child sing two sentences of the shahada in Arabic and its translation. 
In the classroom, children are introduced to the theory and practice of ablution, tayammum and prayer with lectures and directly practiced by the teacher. After being taught a demonstration by the teacher, then the child is invited to the mosque to practice ablution and prayer. Children are taught directly in the water tap by doing the ablution procedures.

In the following week, the child was introduced tayammum. In the classroom, children are introduced to the theory and practice of tayammum and prayer with lectures and directly practiced by the teacher. After being taught a demonstration by the teacher, then the child is invited to the mosque to practice in each child can experience it himself. Children are taught directly on the walls of the mosque by practicing tayammum. The practice of ablution and tayammum is held every Friday.

Children practice ablution and prayer every Friday at the standard Muhammadiyah complex mosque. Children are taught and practiced from prayer to go to the bathroom and prayer after ablution, the prayer of both parents and prayer for the salvation of the hereafter.

Religiosity material is always conditioned by teachers in Aisyiyah Kindergarten through daily activities. That was conveyed by the head of "Aisyiyah Kindergarten:

"We want children to always be conditioned to the religious atmosphere so that not only face-toface material, but direct and indirect activities are conditioned to religious atmosphere and climate so that children feel comfortable in religion."

The statement is truly seen from the schedule of learning conducted every day as follows:

Table 9. Activity Schedule for Religiosity

\begin{tabular}{ll}
\hline Day & Activity \\
\hline Monday & Memorization of short letters (Juz 'Amma) and memorization of \\
& Hadith \\
\hline Tuesday & Daily Prayers and Islamic songs \\
\hline Wednesday & Obedience and Iqra Reading Practice \\
\hline Thursday & Kemuhammadiyahan's poems \\
\hline Friday & - \\
\hline
\end{tabular}

The table shows that between religious material and daily activities are not necessarily synchronous. However, there must be a process of habituation so that children can because it is usually done.

Children's achievements in school are communicated by the teacher through communication books every day so that they are monitored or acted upon. Therefore, children at school often say hello when they meet their friends and enter the room also occurs at home. But if the mastery of the child is not strong at school, the parents let them know so that they can be trained at home by parents.

4.1.2. Inculcation Religiosity in Preschoolers (AUD) in the Santa Maria Kartasura Kindergarten in the 2018/2019 academic year

The Kindergarten of Santa Maria Kartasura is an educational institution based on Catholicism under the auspices of the Canisius Foundation. In accordance with the spirit of the Catholic Faith and Indonesianism, the curriculum used refers to the provisions of the Ministry of National Education 
and the Local Content Curriculum in accordance with the Characteristics of Education owned by the Canisius Foundation. This was stated by the Canisius Kartasura Foundation Management:

"The curriculum at Canisius uses 2 references in order to maintain the unity of Indonesia and the Catholic Faith. MONE Reference is used so that children master the graduate competency standards set by the ministry. Besides that, students are also able to develop their Catholic Faith competencies."

This opinion shows that Santa Maria Kindergarten is trying to make Indonesian children who have Catholic faith so that they can become Indonesian Catholics. This is consistent with the vision which states that:

"Preparing children to become whole persons that is qualified, faithful and virtuous under the protection of the mother of the Church, Santa Maria

The curriculum is strengthened with simple local content by getting children to be familiar with their Lord. Habituation is first done when starting to enter class. Children are trained in morning singing. The morning song reads:

Good morning Lord Jesus,

I give my greetings.

I will pray well,

and according to my mother.

Lord Jesus bless the children at school

so that we are smart and holy throughout our lives.

Inculcation of religiosity through this song is carried out every morning when the child enters the class.

The beginning of the opening is more fun in the context of inculcating children's religiosity so that children do not feel burdened by their religion at least with Jesus. This was confirmed by the head of Santa Maria Kindergarten:

"Child, we introduce and point to Jesus so that we know the name of Jesus in everyday life because this pat is practiced every day. Besides that, children train themselves to animate religious teachings at the beginning of face-to-face learning".

After it is finished, the child enters the thematic learning as planned the day before. Seeing this condition, it seems that religious learning is not integrated with other learning and even looks separate from religious learning with other learning.

Religious Inculcation is seen again when before eating. Children are trained to pray to eat as follows:

Oh, my God,

we thank you for the fortune you gave us.

Thank you, my Lord.

Amin.

This prayer is familiarized by the school so that children become memorized and train themselves to be able to adjust to their prayers. After the prayer is finished, continue with the theme determined the day before. Religious inculcation will be seen again when the children prepare to go home by 
singing first. The path leads the child to the daily introduction of Jesus. After the pat and prayer are over, the child is allowed to go home without having to shake hands with his teacher.

Looking at the explanation above, it can be seen that religious inculcation in Catholics is more dominated by prayers that must be said by all children every day. While in religious practice, less attention is seen when the child enters the classroom shaking hands with his teacher, but when he goes home, he does not shake hands. Santa Maria Kindergarten does not use a communication book between the school and home, so there is no synchronization and synergy between the two. Therefore, there is no control over the sustainability of religious programs on both sides.

\subsection{Discussion}

Inculcation religiosity in children in Playgroups is supported by the environment of educational institutions, teachers, and the learning process. The carrying capacity of religious content is very strong in Aisyiyah Kindergarten because of teacher resources that enable the Inculcation of younger religiosity because it is supported by 3 teachers with religious education backgrounds, namely alumni of Islamic Higher Education. This institution is different from the Santa Maria Kindergarten where almost no teacher has a religious education. Religious Inculcation is seen in terms of the time of the two places studied differently in terms of learning time.

Table 10. Comparison of Entrance Hours and Return Hours

\begin{tabular}{llllll}
\hline Institution & Day & $\begin{array}{l}\text { School } \\
\text { time }\end{array}$ & $\begin{array}{l}\text { Home } \\
\text { time }\end{array}$ & Home time Friday $\begin{array}{l}\text { Home time } \\
\text { Saturday }\end{array}$ \\
\hline $\begin{array}{l}\text { Aisyiyah } \\
\text { Kindergarten }\end{array}$ & $\begin{array}{l}\text { Monday- } \\
\text { Friday }\end{array}$ & 07.30 & 10.00 & 09.30 & Holiday \\
\hline $\begin{array}{l}\text { Santa Maria } \\
\text { Kindergarten }\end{array}$ & $\begin{array}{l}\text { Monday- } \\
\text { Saturday }\end{array}$ & 07.30 & 09.45 & 09.45 & 09.00 \\
\hline
\end{tabular}

The table shows that the research time is longer at the Kindergarten Maria Santa because it starts Monday through Saturday when viewed from the day of research. However, it will be shorter if viewed from the research hours. Although the difference is about 15 minutes. However, if the total is actually Santa Maria Kindergarten, the research hours are the same as Aisyiyah Kindergarten.

The same learning time is given more religious Inculcation on the material side of the Aisyiyah Kindergarten Because the material consists of Aqeedah Morals, al-Qur'an Hadith, Worship, and daily prayers. The habit of praying such as prayer to learn, the prayer of parents, prayers before and after eating, prayers want to learn, prayers before and after sleep and prayers of happiness in the world and the hereafter. This prayer is done every day. This research is almost the same as the findings of (Holloway, 1999) who found that at Buddhist preschool, the curriculum was designed to strengthen children's virtue, intelligence, and physical well-being. Slightly different materials in Buddhist preschool the emphasis is on achieving literacy and numeracy skills. Lessons are delivered in the context of the whole group, with an emphasis on absorbing content rather than encouraging personal exploration and expression.

In addition, habituation to say hello and shake hands when going to school with a teacher. Islamic pat and chanting are also accustomed to the child every day so that it is embedded in the heart of the child's good teachings. Whereas in Santa Maria Kindergarten is more dominant in the habit of praying when entering learning, eating prayer and prayer when going home. Its internalization is through habituation by singing and pat. This model makes the child's acceptance of religious values in a cheerful atmosphere. 
These findings indicate that Early Childhood Education as a substitution of basic education gives children the right care model (Departemen Pendidikan dan Kebudayaan Depdikbud, 2007). This means PAUD is not limited to children's education but is also related to the provision of appropriate care in accordance with the level of growth and development.

The environment for the care and education of Preschoolers is according to Arce, (2000, p. 42) is a place where people interact for the common goal in parenting and educating children. For this reason, the role of parents from the perspective of child development is how parents facilitate, support and assist the development of children not based on the needs of parents (Eva L., 2013, p. 64) so that the development of student religiosity at an early age can be optimal.

\section{CONCLUSION}

Inculcation religiosity in Preschoolers in the Aisyiyah Kindergarten Kartasura Branch uses 2 curricula, namely the curriculum stipulated in the Ministry of Education on Early Childhood Education Standards and the local content curriculum set by PP 'Aisyiyah. Whereas inculcation religiosity in Preschoolers in the Santa Maria Kindergarten in Kartasura Regency uses 2 curriculum references, namely the curriculum stipulated in the Ministry of Education Regulation on Early Childhood Education Standards and the local content curriculum created by the Canisius Foundation.

Inculcation religiosity in the Aisyiyah Kindergarten branch Kartasura has more burdens than in Santa Maria Kindergarten. While its nature is more balanced between the vertical ritual content and the horizontal content on the Aisyiyah Kindergarten branch Kartasura compared to the Santa Maria Kindergarten. The Inculcation of moral education is conducted through the step-by-step process starting with teaching to say and answer greetings (Islam), saying good morning and afternoon to non-Muslims and inviting children to always pray at any activity.

Vertical ritual Inculcation in Aisyiyah Kindergarten branch Kartasura has more burden through the practice of prayer, memorizing prayers, and memorizing short letters from the Qur'an all in Arabic compared to Santa Maria Kindergarten which only emphasizes the memorizing of prayers in the Indonesian language. The habit of religiosity in preschoolers requires teachers who are able to master the material related to religiosity so that to offer examples and examples will get good results.

\section{REFERENCES}

Adams, K., Bull, R., \& Maynes, M. L. (2016). Early childhood spirituality in education: Towards an understanding of the distinctive features of young children's spirituality. European Early Childhood Education Research Journal, 24(5), 760-774. https://doi.org/10.1080/1350293X.2014.996425

Arce, E.-M. (2000). Curriculum for Young Children: An Introduction. (New York: Delmar Thomson Learning.

Banerjee, K., \& Bloom, P. (2015). "Everything Happens for a Reason": Children's Beliefs About Purpose in Life Events. Child Development, 86(2), 503-518. https://doi.org/10.1111/cdev.12312

Benson, P. L., Scales, P. C., Syvertsen, A. K., \& Roehlkepartain, E. C. (2012). Is youth spiritual development a universal developmental process? An international exploration. Journal of Positive Psychology, 7(6), 453-470. https://doi.org/10.1080/17439760.2012.732102

Bridges, L. J., \& Moore, K. a. (2002). Religion and Spirituality in Childhood and Adolescence. Child Trends, 1-59. Retrieved from http://www.childtrends.org/wp- 
content/uploads/2002/01/Child_Trends-2002_01_01_FR_ReligionSpiritAdol.pdf

Davies, T. (2019). Religious education and social literacy: the 'white elephant' of Australian public education. British Journal of Religious Education, 41(2), 124-133. https://doi.org/10.1080/01416200.2017.1324758

Departemen Pendidikan dan Kebudayaan Depdikbud. (2007). Pedoman Teknis Penyelenggaraan Pos PAUD:(Direktorat PAUD, 2006) Direktorat PAUD Grand Design Program Pendidikan Anak Usia Dini Non- formal tahun 2007-20015. Indonesia.

Eva L., E. (2013). Introduction to Early Childhood Education. Belmont: Wadsworth.

Fisher, J. (2013). Assessing spiritual well-being: Relating with God explains greatest variance in spiritual well-being among Australian youth. International Journal of Children's Spirituality, 18(4), 306-317. https://doi.org/10.1080/1364436X.2013.844106

Granqvist, P., \& Nkara, F. (2017). Nature meets nurture in religious and spiritual development. British Journal of Developmental Psychology, 35(1), 142-155. https://doi.org/10.1111/bjdp.12170

Heiphetz, L., Lane, J. D., Waytz, A., \& Young, L. L. (2016). How Children and Adults Represent God's Mind. Cognitive Science, 40(1), 121-144. https://doi.org/10.1111/cogs.12232

Henderson, A. K. (2016). The Long Arm of Religion: Childhood Adversity, Religion, and Selfperception Among Black Americans. Journal for the Scientific Study of Religion, 55(2), 324-348. https://doi.org/10.1111/jssr.12262

Holloway, S. D. (1999). The Role of Religious Beliefs in Early Childhood Education: Christian and Buddhist Preschools in Japan. ERCP Early Chilhood Research and Practice, 1(2). Retrieved from http://ecrp.illinois.edu/v1n2/holloway.html

Kienstra, N., van Dijk-Groeneboer, M., \& Boelens, O. (2018). Religious-Thinking-Through Using Bibliodrama: An Empirical Study of Student Learning in Classroom Teaching. Religious Education, 113(2), 203-215. https://doi.org/10.1080/00344087.2017.1403788

King, U. (2013). The spiritual potential of childhood: Awakening to the fullness of life. International Journal of Children's Spirituality, 18(1), 4-17. https://doi.org/10.1080/1364436X.2013.776266

Rissanen, I., Kuusisto, E., Hanhimäki, E., \& Tirri, K. (2018). The implications of teachers' implicit theories for moral education: A case study from Finland. Journal of Moral Education, 47(1), 63-77. https://doi.org/10.1080/03057240.2017.1374244

Scott, K. (2014). Inviting young adults to come out religiously, institutionally and traditionally. Religious Education, 109(4), 471-484. https://doi.org/10.1080/00344087.2014.924790

Suyadi, Destiyanti, A. Z., \& Sulaikha, N. A. (2019). Perkembangan Nilai Agama-Moral Tidak Tercapai pada Anak Development of Religious-Moral Values Not Reached in Basic Age Children : A Case Study in Class SD Muhammadiyah. 6(1), 1-12. 